\title{
Vertebrate diversity reveals perturbations in faunal communities prior to the Hangenberg event in the Montagne Noire (France)
}

\author{
Alexandre Assemat, Catherine Girard, Michael M. Joachimski \& Sylvain Adnet
}

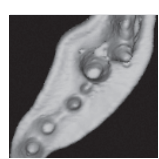

\begin{abstract}
The Hangenberg crisis represents a mass extinction marked by a biodiversity turnover at the Devonian-Carboniferous boundary. However, the last million years before this dramatic event have been poorly investigated. Here we report new data on the size and abundances of vertebrate remains as well as carbon isotope data from the latest Famennian in the Montagne Noire (France). A significant decrease in fish abundance and a general reduction in the size of vertebrate remains are observed during a period of stable environment before the onset of the Hangenberg crisis. No perturbations are recorded by the carbon isotopes, supporting the stability of the environment. This significant change in the structuration of vertebrate communities prior to the Hangenberg crisis is not linked to any turnover in other faunal groups. That could be interpreted as changes in faunal repartition that predate mass extinctions. - Key words: Famennian, Hangenberg, vertebrate teeth, Montagne Noire, vertebrate diversity, carbon isotopes.
\end{abstract}

Assemat, A., Girard, C., Joachimski, M.M. \& Adnet, S. 2022. Vertebrate diversity reveals perturbations in faunal communities prior to the Hangenberg event in the Montagne Noire (France). Bulletin of Geosciences 97(1), 109-122 (5 figures, 3 tables). Czech Geological Survey, Prague. ISSN 1214-1119. Manuscript received March 26, 2021; accepted in revised form October 4, 2021; published online November 20, 2021; issued January 23, 2022.

Alexandre Assemat, Catherine Girard \& Sylvain Adnet, ISEM, Univ Montpellier, CNRS, EPHE, IRD, Montpellier, France; alexandre.assemat@umontpellier.fr•Michael M. Joachimski, GeoZentrum Nordbayern, Friedrich-Alexander Universität Erlangen-Nuremberg (FAU) Schlossgarten 5, 91054 Erlangen, Germany

From the first diversifications to modern times, life has been regularly subject to crises (Roberts \& Mannion 2019). While some perturbations only poorly affected diversity, others had a deep impact and shaped the general organization of ecosystems (Sepkoski 1996). During the Phanerozoic, five mass extinction events have been recognized as the "Big Five" due to their impact on species communities, leading to extinction and later recovery (Walliser 1996, Bambach et al. 2004). The Late Devonian is known for one of the big five crises at the Frasnian-Famennian boundary (F-F) (Raup \& Sepkoski 1982, McGhee 1996, Stigall 2012). 13 million years later, another major perturbation now recognized of the same "Big Five" magnitude occurred at the DevonianCarboniferous (D-C) boundary (McGhee et al. 2013, Kaiser et al. 2015). This crisis affected faunal diversity on land and in the oceans and is known as the Hangenberg mass extinction event (Walliser 1984, Paproth et al. 1991, Feist et al. 2000). The Hangenberg crisis has been described as a multi-phased event that started at around $359.5 \mathrm{Ma}$ (Becker et al. 2012), in the Bispathodus ultimus Zone (slightly below the former middle praesulcata Zone) and reached into the Protognathodus kockeli Zone (slightly above the former praesulcata-sulcata boundary) (Aretz 2020, Kaiser et al. 2020) (Fig. 1).
The 13 million years between the $\mathrm{F}-\mathrm{F}$ and $\mathrm{D}-\mathrm{C}$ crises seem to be punctuated by minor biological events and turnovers of various magnitude (Walliser 1996, Paschall et al. 2019, Girard et al. 2020), which may have been related to climate change (Kaiser et al. 2008, Isaacson et al. 2008), tectonic (Averbuch et al. 2005) and volcanic activities (Kravchinsky 2012) as well as the development of complex terrestrial plant ecosystems (Decombeix et al. 2011). At the same time eustatic sea level changes occurred as consequence of the onset of Gondwana glaciation (Isaacson et al. 2008).

Several bio-events are recognized before the last $1 \mathrm{my}$ before the Hangenberg crisis. The last two bio-events of this interval are the Epinette (361.5 Ma) and Etroeungt (361 Ma) events (latest Famennian) which have been reported from different locations worldwide (Kaiser et al. 2008) (Fig. 1). These bio-events have been associated to positive carbon isotope excursions (Kaiser et al. 2008). Such positive carbon isotopes excursions are mostly correlated to eustatic sea level variations and for example weathering intensity and/or nutrient supply (Buggisch \& Joachimski 2006).

The aim of the present contribution was to study changes in vertebrate biodiversity during the Hangenberg pre-crisis (360-359 Ma), in a time period between the 


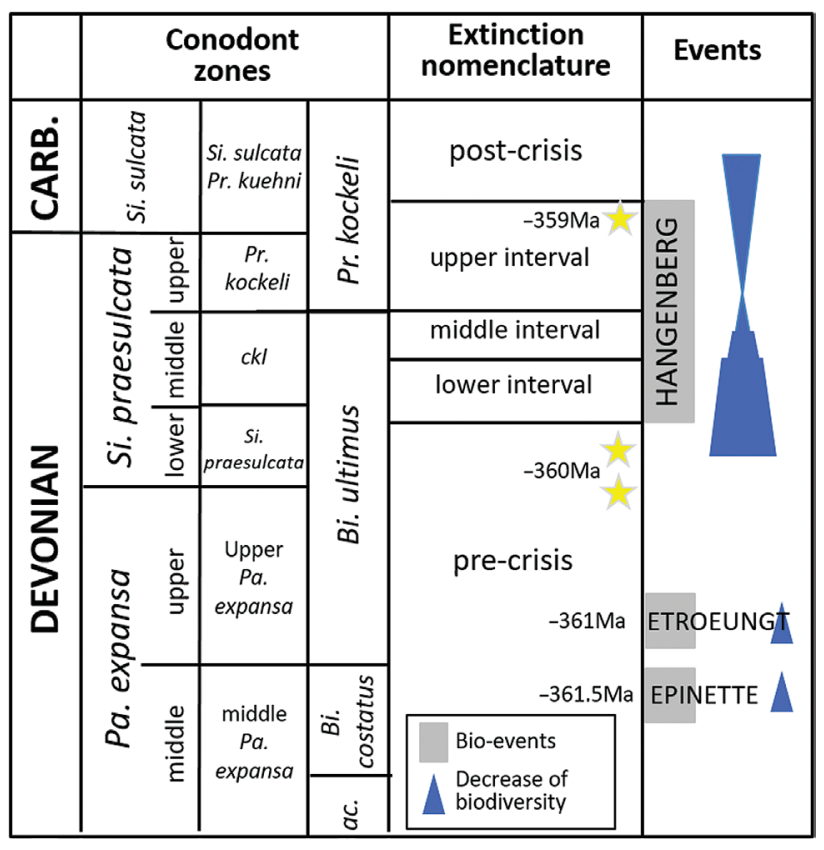

Figure 1. Temporal context of Late Famennian bio-events (after Aretz 2020). Conodont zones after Ziegler \& Sandberg (1990) on the left, Kaiser et al. (2009) in the middle and Spalletta et al. (2017) on the right. Extinction nomenclature after Aretz (2020); location of the Epinette and Etroeungt events after Kaiser et al. (2008). Yellow stars: position of studied samples. Abbreviations: CARB. - Carboniferous; Pa. - Palmatolepis; Si. - Siphonodella; Pr. - Protognathodus; Bi. Bispathodus; ac. - aculeatus; ckl-costatus-kockeli interregnum.

Etroeungt and Hangenberg events that corresponds to the Wocklum limestone (sensu Becker et al. 2016), which was previously interpreted as a relatively quiet interval (Aretz 2020) and to compare latest Famennian biodiversity with post Hangenberg biodiversity (359 Ma) (Fig. 1). While crises and post-crisis recovery periods have been widely studied, most investigations focused on the aspect of faunal renewal at the species level (Girard 1994, Ziegler \& Lane 1987, Lelievre \& Derycke 1998, Kulagina et al. 2021). This approach accentuates the catastrophic nature of the crises by highlighting extinctions followed by the appearance of new species in periods that are by definition exceptional.

Our study was conducted to study the dynamic of vertebrate communities around a mass extinction, with no restriction to the taxonomic species level, and under assumed stable environmental conditions.

To address this question, we focused on the Col des Tribes section in the Montagne Noire, considered as a reference section for the Famennian (Girard et al.
2014). The uppermost part of the Famennian and the period following the Hangenberg event were sampled for geochemistry and faunal content. Carbon isotopes have been used as they are generally good proxies for locating environmental perturbations (Joachimski et al. 2002, Goddéris \& Joachimski 2004). For the diversity study, vertebrate remains were chosen, due to their good preservation potential as consequence of their hydroxyapatite mineralogy. Chondrichthyan, actinopterigyan and conodont teeth remains were studied in detail as they are common and well-preserved in this section (Gauchey et al. 2014). The taxonomic diversity, abundance and size of the teeth were considered. Combining these three aspects, and geochemical data allow a multi-proxy study of the vertebrate fauna in their environment.

While conodonts have been the subject of numerous studies in the Montagne Noire area (e.g. Feist \& Flajs 1987, Girard \& Albarède 1996, Girard et al. 2014, Girard et al. 2020), other coeval marine vertebrate remains have not received as much attention (Derycke et al. 1995, Ginter 2000, Gauchey et al. 2014) especially around the D-C boundary. Here we consider the diversity of the contemporaneous vertebrate groups in order to 1) analyse vertebrate diversity in a close time span that encompass the Hangenberg event and 2) perform a geochemical study of carbon isotopes across the Devonian-Carboniferous boundary.

\section{Geological setting}

The studied material has been collected in the carbonate succession of the Col des Tribes section, situated on the eastern slope of the Mont Peyroux in the Montagne Noire area (South France), with special focus to some levels around the Hangenberg crisis (Fig. 2).

Three levels that encompass the Hangenberg crisis have been considered. Two samples from the middle part of the CT69-7 and the base of the CT70-A level were taken before the onset of the Hangenberg crisis (Fig. 2). One sample was collected at the base of the recovery phase of the Hangenberg crisis at level CT70-5 (equivalent of the DC2 to DC4 levels of Feist et al. 2020) (Fig. 2).

\section{Fossil separation}

Four-kilogram carbonate rocks were dissolved for sample CT69-7, five-kilogram for CT70-A and CT70-5.

Figure 2. Col des Tribes (CT) section (Montagne Noire, France). $\bullet$ A - simplified geological map of the Montagne Noire (modified from Aretz et al. 2016) and position of the Col des Tribes section. $・ \mathrm{~B}$ - stratigraphical log. $\bullet \mathrm{C}-$ facies. $・ \mathrm{D}$ - carbon isotopes (in \% V-PDB) and proportion of fossil remains in each sampled level. Diameter of the circular diagram is proportional to the number of specimens per $\mathrm{kg}$. $\cdot \mathrm{E}-\mathrm{column}$ plot of the fossil remain abundance $(\log )$ in function of the different sieves used for the decalcification. 
Alexandre Assemat et al. • Vertebrate diversity reveals perturbations in faunal communities prior to the Hangenberg event

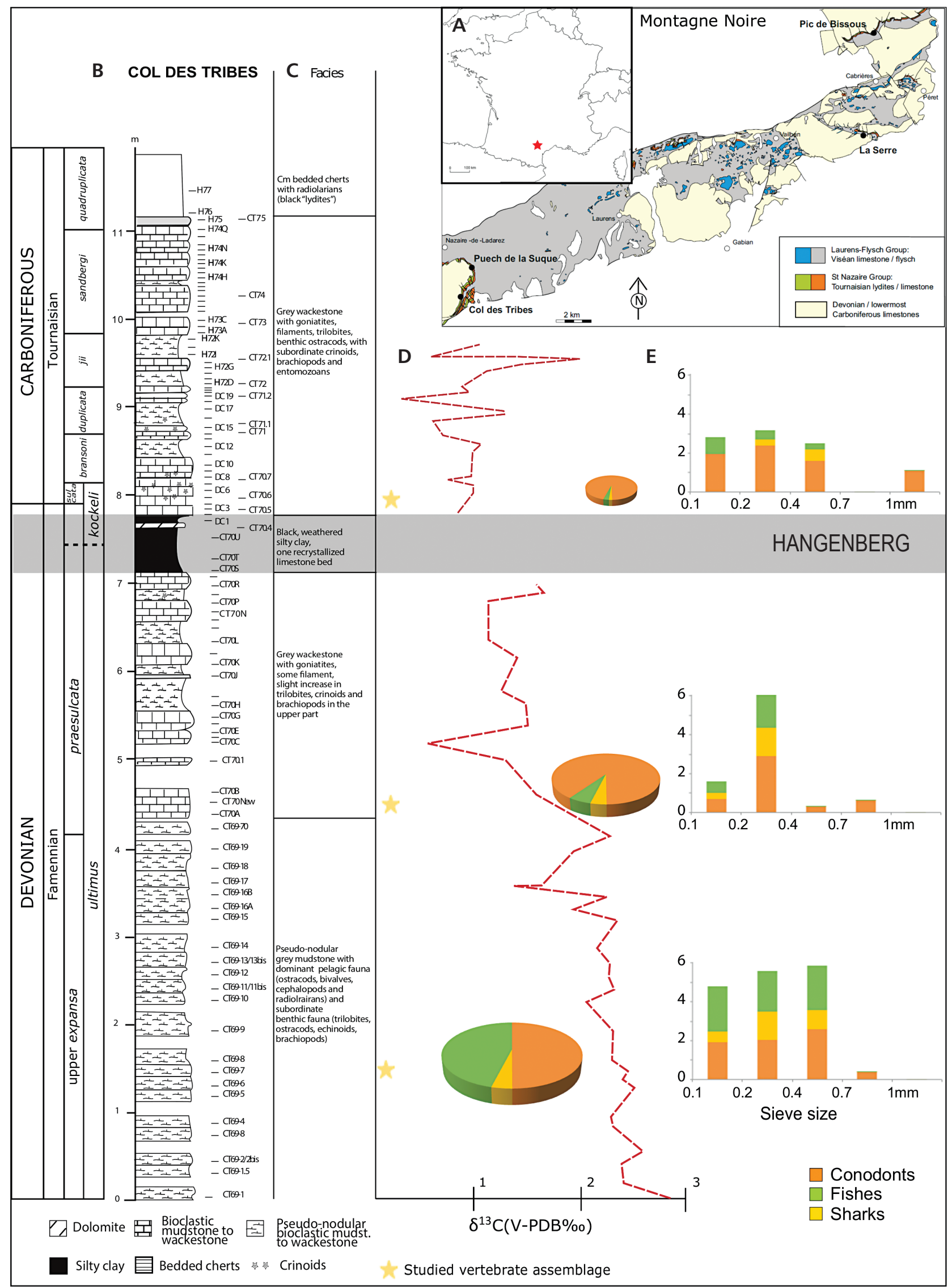


Table 1. Repartition of fossil remains per level regarding to their size (using sieves size as determination for size groups), sample numbers and fossil data for the $\mathrm{Col}$ des Tribes section (France). Weight: total dissolved samples in kilograms, abundance of the different groups per sieve size categories, total of the teeth remains per sample. Abbreviation: elem. - elements.

\begin{tabular}{|c|c|c|c|c|c|c|c|c|c|}
\hline Sample & Fraction & $>1 \mathrm{~mm}$ & $1>>0.7 \mathrm{~mm}$ & $0.7>>0.4 \mathrm{~mm}$ & $0.4>>0.2 \mathrm{~mm}$ & $0.2>>0.1 \mathrm{~mm}$ & Total & Weight & $\mathrm{W} / \mathrm{kg}$ \\
\hline CT70-5 & TOTAL & 12 & 0 & 46 & 258 & 99 & 415 & 5 & 83 \\
\hline CT70-5 & Conodonts P1 elem. & 12 & 0 & 40 & 253 & 91 & 396 & & \\
\hline CT70-5 & Sharks & 0 & 0 & 4 & 2 & 1 & 7 & & \\
\hline CT70-5 & Fishes & 0 & 0 & 2 & 3 & 7 & 12 & & \\
\hline CT70-A & TOTAL & 0 & 5 & 3 & 770 & 11 & 789 & 5 & 158 \\
\hline CT70-A & Conodonts P1 elem. & 0 & 4 & 2 & 692 & 5 & 703 & & \\
\hline CT70-A & Sharks & 0 & 1 & 1 & 31 & 2 & 35 & & \\
\hline CT70-A & Fishes & 0 & 0 & 0 & 47 & 4 & 51 & & \\
\hline СT69-7 & TOTAL & 2 & 3 & 458 & 212 & 226 & 901 & 4 & 225 \\
\hline СТ69-7 & Conodonts P1 elem. & 0 & 2 & 298 & 86 & 64 & 450 & & \\
\hline СT69-7 & Sharks & 1 & 1 & 8 & 23 & 3 & 36 & & \\
\hline СТ69-7 & Fishes & 1 & 0 & 152 & 103 & 159 & 415 & & \\
\hline
\end{tabular}

Cycles of $24 \mathrm{hrs}$ acid bath $(10 \%$ formic acid or acetic acid) followed by $30 \mathrm{~min}$ washing of the residues were performed. The number of dissolution cycles varied for each sample due to varying clay contents stopping more or less the decalcification. We used 1, 0.7, 0.4, 0.2, and $0.1 \mathrm{~mm}$ sieves to separate the residues. Every fraction has been sorted separately in order to analyze more precisely the abundance of the teeth according to their size, and to estimate the proportion of respective size remains in each sample (Tab. 1).

As the quantity of dissolved sediments varied for each sample, we normalized the extracted tooth elements to $1 \mathrm{~kg}$ sediment in order to compare the abundance of specimens per sample. Following, we estimated the absolute abundance in percent among the different samples. All data are presented in the Table 2.

For illustration purposes, some specimens have been scanned using the SFR Biosciences (UMS3444/CNRS,
US8/Inserm, ENS de Lyon, UCBL) AniRa-ImmOs facility. The surfaces were extracted slice-by-slice manually within AVIZO 9.0 (Visualization Sciences Group) and then oriented for illustration using the MorphoDig freeware (Lebrun 2018).

Specimens are hosted in the collections of the University of Montpellier (UM) France, and are listed in the caption of Figure 3.

Taxonomical determinations and occurrences are reported in Ginter (2000), Girard et al. (2014) and Feist et al. (2020).

\section{Geochemical analyses}

We performed carbon isotope analyses on the carbonates from the base of level CT69 (Late Famennian) to H73 (early Tournaisian, Fig. 2D) by sampling every carbonate

Table 2. Numerical data for the Col des Tribes section (Montagne Noire, France). Abundance of the different genera of chondrichthyes and conodonts P1 elements, and abundance of the bony fish teeth. Abbreviations: Bi. - Bispathodus; Po. - Polygnathus; Pa. - Palmatolepis; Pr. - Protognathodus; Br. - Branmehla; Ja. - Jalodus; Ph. - Phoebodus; Si. - Siamodus; Th. - Thrinacodus; Pro. - Protacrodus.

\begin{tabular}{lcccccccccccccc}
\hline Level/Taxa & Bi. & Po. & $P a$. & $P r$. & Br. & Ja. & Ph. & Si. & Th. & Pro. & $\begin{array}{c}\text { Sharks } \\
\text { indet }\end{array}$ & $\begin{array}{c}\text { Fishes } \\
\text { Total }\end{array}$ & $\begin{array}{c}\text { Total/ } \\
\mathrm{kg}\end{array}$ \\
\hline CT70-5 & 73 & 179 & 0 & 67 & 77 & 0 & 0 & 0 & 1 & 2 & 5 & 12 & 416 & 83 \\
CT 70-A & 355 & 197 & 120 & 0 & 31 & 23 & 3 & 3 & 0 & 0 & 6 & 51 & 789 & 158 \\
CT69-7 & 183 & 125 & 60 & 0 & 82 & 21 & 0 & 6 & 0 & 0 & 9 & 415 & 901 & 225 \\
\hline
\end{tabular}


Alexandre Assemat et al. • Vertebrate diversity reveals perturbations in faunal communities prior to the Hangenberg event

Table 3. Stable isotope data $\left(\delta^{13} \mathrm{C}\right)$ of the Col des Tribes section (France). Values in italics indicate that the samples were recrystallized and not included in the analysis due to their negative values.

\begin{tabular}{|c|c|c|c|c|c|}
\hline Date & Strati & $\delta^{13} \mathrm{C} \% \mathrm{~V}-\mathrm{PDB}$ & Date & Strati & $\delta^{13} \mathrm{C} \%$ V-PDB \\
\hline $03 / 23 / 17$ & СТ68-8 & 2.89 & $06 / 16 / 14$ & CT 70j & 1.38 \\
\hline $06 / 23 / 20$ & СТ 69-1 & 2.40 & $06 / 18 / 14$ & $C T 70 K$ & -0.20 \\
\hline $06 / 23 / 20$ & СТ 69-1.5 & 2.41 & $06 / 19 / 14$ & СТ 70.2 & 1.08 \\
\hline $06 / 23 / 20$ & СТ 69-2 & 2.59 & $06 / 18 / 14$ & CT 70L & 1.04 \\
\hline $06 / 23 / 20$ & CT 69-2bis & 2.62 & $06 / 19 / 14$ & CT 70L & 1.14 \\
\hline $06 / 23 / 20$ & СТ 69-3 & 2.31 & $06 / 16 / 14$ & CT 70M & 1.66 \\
\hline $06 / 23 / 20$ & СТ 69-4 & 2.29 & $06 / 19 / 14$ & CT $70 \mathrm{~N}$ & 1.54 \\
\hline $06 / 23 / 20$ & CT 69-5 & 2.51 & $06 / 18 / 14$ & $C T 70 P$ & -0.70 \\
\hline $06 / 23 / 20$ & СТ 69-6 & 2.40 & $06 / 19 / 14$ & $C T 70 Q$ & -0.82 \\
\hline $06 / 23 / 20$ & СТ 69-7 & 2.45 & $06 / 18 / 14$ & CT 70.R & -0.55 \\
\hline $06 / 23 / 20$ & СТ 68-8 & 2.30 & $06 / 18 / 14$ & $D C 2$ & -2.17 \\
\hline $06 / 23 / 20$ & СТ 69-9 & 2.34 & $06 / 19 / 14$ & DC 3 & 0.81 \\
\hline $06 / 23 / 20$ & СТ 69-10 & 2.05 & $06 / 18 / 14$ & $D C 4$ & -0.36 \\
\hline $06 / 23 / 20$ & СТ 69-11 & 2.45 & $06 / 16 / 14$ & DC 6 & 0.96 \\
\hline $06 / 23 / 20$ & CT 69-11bis & 2.25 & $06 / 19 / 14$ & DC-7 & 0.95 \\
\hline $06 / 23 / 20$ & СТ 69-12 & 2.27 & $06 / 18 / 14$ & DC 8 & 0.69 \\
\hline $06 / 23 / 20$ & СТ 69-13 & 2.26 & $06 / 19 / 14$ & DC-9 & 0.92 \\
\hline $06 / 23 / 20$ & СТ 69-13bis & 2.34 & $06 / 18 / 14$ & DC 10 & -0.07 \\
\hline $06 / 23 / 20$ & CT 69-14 & 2.13 & $06 / 16 / 14$ & $D C-11$ & -0.65 \\
\hline $06 / 23 / 20$ & CT 69-15 & 2.36 & $06 / 16 / 14$ & DC-13 & 0.95 \\
\hline $06 / 23 / 20$ & СТ 69-16a & 1.91 & $06 / 19 / 14$ & DC-14 & 1.03 \\
\hline $06 / 23 / 20$ & СТ 69-16b & 2.28 & $06 / 19 / 14$ & DC 15 & 0.66 \\
\hline $06 / 23 / 20$ & CT 69-17 & 1.32 & $06 / 16 / 14$ & $D C-16$ & -1.12 \\
\hline $06 / 23 / 20$ & СТ 69-18 & 1.73 & $06 / 16 / 14$ & DC 17 & 0.56 \\
\hline $06 / 23 / 20$ & СТ 69-19 & 1.89 & $06 / 19 / 14$ & DC-18 & 1.25 \\
\hline $06 / 23 / 20$ & СТ 69-70 & 2.27 & $06 / 18 / 14$ & DC-19 & 1.24 \\
\hline $06 / 23 / 20$ & CT 70-1 inf & 1.90 & $06 / 19 / 14$ & H 72A & 1.11 \\
\hline $06 / 23 / 20$ & CT 70-1sup & 1.41 & $06 / 16 / 14$ & H 72B & 1.13 \\
\hline $06 / 19 / 14$ & СТ 70-1 & 1.26 & $06 / 19 / 14$ & $\mathrm{H} 72 \mathrm{C}$ & 0.99 \\
\hline $06 / 19 / 14$ & СТ 70A & 2.04 & $06 / 19 / 14$ & H 72D & 0.75 \\
\hline $06 / 16 / 14$ & CT 70b & 2.12 & $06 / 16 / 14$ & $\mathrm{H} 72 \mathrm{E}$ & 0.24 \\
\hline $06 / 19 / 14$ & СТ 70B & 1.20 & $06 / 19 / 14$ & $\mathrm{H} 72 \mathrm{~F}$ & 0.68 \\
\hline $06 / 18 / 14$ & CT 70-C & 0.44 & $06 / 18 / 14$ & $\mathrm{H} 72 \mathrm{G}$ & 0.91 \\
\hline $06 / 19 / 14$ & CT 70D & 0.86 & $06 / 19 / 14$ & $\mathrm{H} 72 \mathrm{H}$ & 0.81 \\
\hline $06 / 16 / 14$ & CT 70E & 1.49 & $06 / 16 / 14$ & H 72K & 1.10 \\
\hline $06 / 16 / 14$ & $C T 70-F$ & -0.07 & $06 / 19 / 14$ & H 73A & 1.43 \\
\hline $06 / 19 / 14$ & CT 70G & 1.46 & $06 / 19 / 14$ & H 73B & 2.01 \\
\hline $06 / 19 / 14$ & СТ $70 \mathrm{H}$ & 1.22 & $06 / 16 / 14$ & H 73C & 0.52 \\
\hline
\end{tabular}


bed to obtain the finest possible resolution. Twenty-five samples were collected from CT69, while two samples were collected at the base of CT70. The new data are combined with unpublished analyses on samples from beds CT70 and CT71 performed in 2014. We collected carbonate powders using a microdrill.

Carbonate powders were reacted with $100 \%$ phosphoric acid at $70^{\circ} \mathrm{C}$ using a Gasbench II connected to a ThermoFisher Delta V Plus mass spectrometer at the University of Erlangen-Nuremberg/Germany. All values are reported in per mil relative to V-PDB. Reproducibility and accuracy were monitored by replicate analysis of laboratory standards calibrated by assigning $\delta^{13} \mathrm{C}$ values of $+1.95 \%$ to NBS19 and $-46.6 \%$ to LSVEC. Reproducibility for $\delta^{13} \mathrm{C}$ was \pm 0.05 ( 1 std. dev.). Carbon isotope values are presented in Table 3.

\section{Results}

In the three studied levels (CT69-7, CT70-A, CT70-5), hundreds of fossils remains mostly composed of conodonts P1 elements but also bony fish teeth (thereafter called fish) and less abundant shark teeth have been found. Representative specimens are shown in Figure 3. Some undissolved foraminifera, and rare crustaceans and scales have also been recovered from these levels.

The analysis of the conodont, fish and shark remains from the three levels permits to document heterogeneity between and among the levels concerning specimen size, abundance and diversity (Tabs 1, 2; Figs 2, 3).

\section{Relative richness}

In total 225 specimens (conodonts, fish and sharks) per kilogram were recovered from sample CT69-7, 158 specimens $/ \mathrm{kg}$ in CT70-A, and 83 specimens/kg in CT70-5 (Fig. 2D, Tab. 2).

Pre-Hangenberg levels (CT69-7 versus CT70-A). - The CT69-7 level displays a comparable abundance of fish teeth and conodonts ( $46.1 \%$ fish teeth, $49.9 \%$ conodonts, $4 \%$ shark teeth) while CT70-A displays a drastic loss in fish teeth but higher relative abundance of conodonts (6.5\% fish teeth, $89.1 \%$ conodonts, $4.4 \%$ shark teeth) (Tabs 1, 2; Fig. 3).

The difference is even more significant when richness is expressed in number of specimens per $\mathrm{kg}$. The number of specimens per $\mathrm{kg}$ decrease from: fish $=104$, conodont $=$ 112 and shark $=9$ in CT69-7 to fish $=12$, conodont $=$ 165 , shark $=8$ in CT70-A, highlighting ten times less fishes per kg in CT70-A than in CT69-7 and an increase in conodonts per $\mathrm{kg}$.
Relative abundance of conodonts doubles between the CT69-7 sample and the CT70-A sample but the proportion of each genus remains the same in both levels ( $\sim 15 \%$ of Palmatolepis, $\sim 45 \%$ of Bispathodus, $\sim 28 \%$ of Polygnathus, $\sim 12 \%$ of Branmehla and Mehlina). Shark tooth relative abundance does not vary between CT69-7 and CT70-A, and remains low ( $\sim 4$ to $4.4 \%$ ).

Post Hangenberg (CT70-5). - While the levels below the Hangenberg crises are fossil-rich, fossils in the postHangenberg deposits are very scarce and often damaged (Fig. 3). In the CT70-5 level, remains are $95 \%$ conodonts, $2 \%$ sharks and $3 \%$ fishes corresponding to 2.5 fish, 79 conodont and 1.5 shark remains per $\mathrm{kg}$. This shows that despite the number of specimens decreased during the Hangenberg crisis, a similar distribution is observed compared to the pre-Hangenberg level CT70-A.

\section{Vertebrate diversity}

Even if they are the most abundant remains, conodonts appear to be represented by nearly as many genera as sharks. Seven conodont genera (Bispathodus, Polygnathus, Palmatolepis, Protognathodus, Branmehla, Mehlina and Pseudopolygnathus) and five genera of shark (Siamodus, Jalodus, Protracrodus, Thrinacodus, Phoebodus) are reported from the three levels. Fish teeth are represented by short to elongated cone-like remains (Fig. 3). Due to the poorly diagnosic features of these conic teeth, they can be determined neither at a species level nor at a generic level and remain in open nomenclature (Gauchey et al. 2014). Fishes are also represented by some scales, that likely belong to paleoniscoids and acanthods (according to Lelievre \& Derycke 1998).

Pre-Hangenberg assemblages (CT69-7 and CT70-A).The conodont assemblages from the pre-Hangenberg levels are dominated by the abundance of Polygnathus (some scarce representatives of Pseudopolygnathus are also reported) and the complex of genera without platform composed by Bispathodus, Branmehla and Mehlina. Regarding the sharks, Famennian chondrichthyes remains in CT69-7 and CT70-A are dominated by the assemblage of Jalodus and Siamodus but also present are some representatives of the genus Phoebodus. No changes are reported in fish morphologies between these two levels.

Post-Hangenberg assemblages (CT70-5). - The conodont assemblage in sample CT70-5 is marked by the disappearance of Palmatolepis and its replacement by Protognathodus, which has a relative abundance at this level close to the one previously observed for the Palmato- 


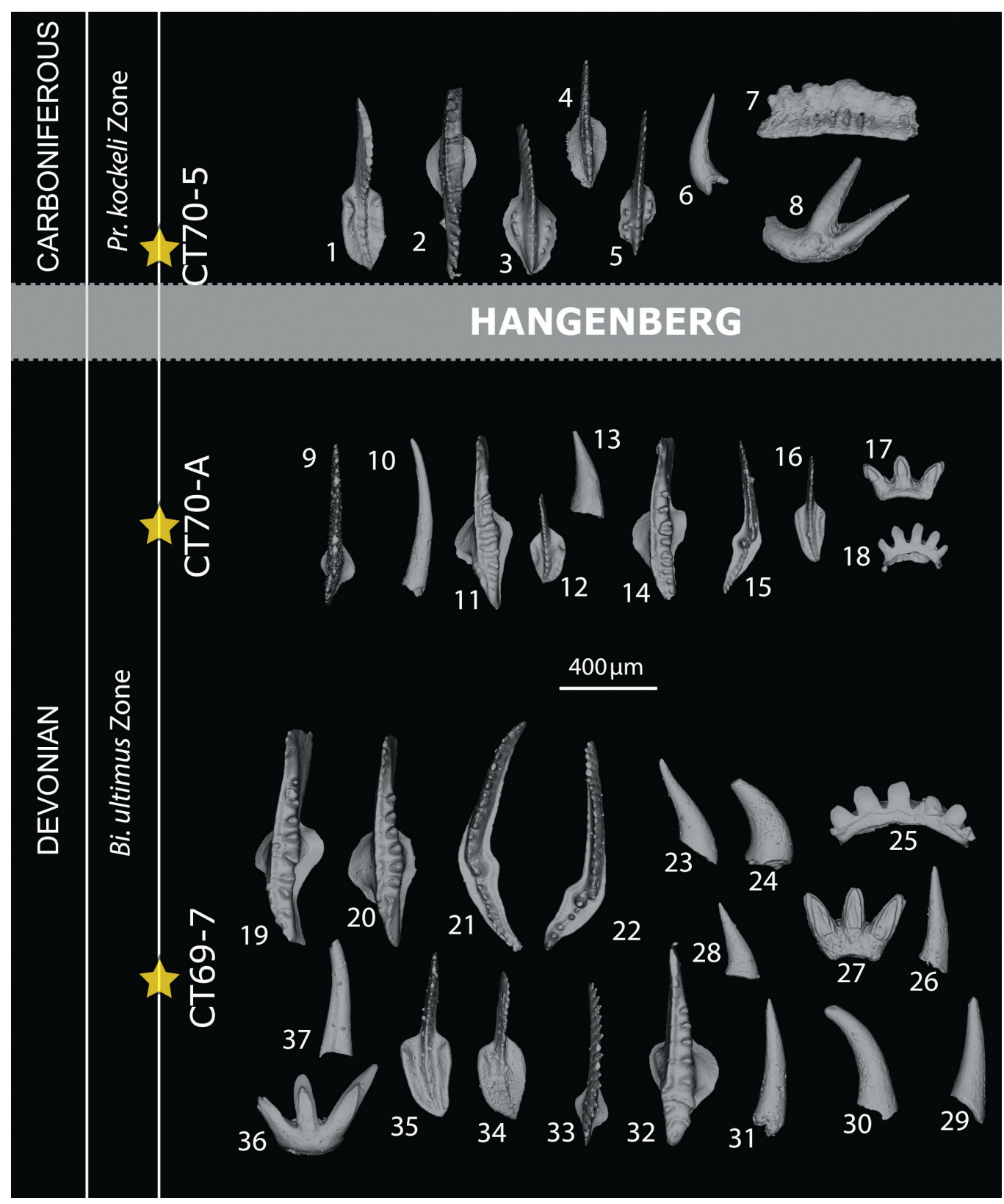

Figure 3. Some representative teeth remains of conodonts, chondrichthyes and actinopterygian fishes illustrating their abundance and diversity in the three studied samples of the Col des Tribes section (France). 1 1-8 - sample CT70-5; 1 - Polygnathus communis dentatus Druce 1969 (UM CTB 041); 2 - Bispathodus aculeatus aculeatus (Branson \& Mehl 1934a) (UM CTB 042); 3 - Protognathodus kockeli (Bischoff 1957) (UM CTB 043); 4 - Bispathodus stabilis (Branson \& Mehl 1934a) (UM CTB 044); 5 - Protognathodus kockeli (Bischoff 1957) (UM CTB 045); 6 - Actinopterygii gen. et sp. indet. (UM CTB 046); 7 - Protacrodonte indet. (UM CTB 047); 8 - Thrinacodus ferox (Turner 1982) (UM CTB 048). 9-18 - sample CT70-A; 9 - Branmehla inornata (Branson \& Mehl 1934a) (UM CTB 049); 10 - Actinopterygii gen. et sp. indet. (UM CTB 050); 11 - Bispathodus ultimus (Bischoff 1957) (UM CTB 051); 12 - Polygnathus communis dentatus Druce 1969 (UM CTB 052); 13 - Actinopterygii gen. et sp. indet. (UM CTB 053); 14 - Bispathodus spinulicostatus (Branson 1934) (UM CTB 054); 15 - Palmatolepis gracilis gracilis Branson \& Mehl 1934a (UM CTB 055); 16 - Polygnathus communis communis Branson \& Mehl 1934b (UM CTB 056); 17 - Jalodus australiensis Long (1990) (UM CTB 057); 18 - Siamodus janvieri Long (1990) (UM CTB 058). •19-37- sample CT69-7; 19 - Bispathodus costatus (Branson 1934) (UM CTB 059); 20 - Bispathodus costatus (Branson 1934) (UM CTB 060); 21 - Palmatolepis gracilis gracilis Branson \& Mehl 1934a (UM CTB 061); 22 - Palmatolepis gracilis gracilis Branson \& Mehl 1934a (UM CTB 062); 23 - Actinopterygii gen. et sp. indet. (UM CTB 063); 24 - Actinopterygii gen. et sp. indet. (UM CTB 064); 25 - Siamodus janvieri Long (1990) (UM CTB 065); 26 - Actinopterygii gen. et sp. indet. (UM CTB 066); 27 - Jalodus australiensis Long (1990) (UM CTB 067); 28 - Actinopterygii gen. et sp. indet. (UM CTB 068); 29 - Actinopterygii gen. et sp. indet. (UM CTB 069); 30 - Actinopterygii gen. et sp. indet. (UM CTB 070); 31 - Actinopterygii gen. et sp. indet. (UM CTB 071); 32 - Branmehla inornata (Branson \& Mehl 1934a) (UM CTB 072); 33 - Bispathodus costatus (Branson 1934) (UM CTB 073); 34 - Polygnathus communis communis Branson \& Mehl 1934b (UM CTB 074); 35 - Polygnathus communis communis Branson \& Mehl 1934b (UM CTB 075); 36 - Jalodus australiensis Long (1990) (UM CTB 076); 37 - Actinopterygii gen. et sp. indet. (UM CTB 077). 
lepis. Nevertheless, the Bispathodus/Branmehla/Mehlina complex shows a minor relative abundance compensated by an increase in Polygnathus remains. Protacrodont sharks and the only specimen of Thrinacodus only occur in the post Hangenberg CT70-5 level replacing the previously dominant assemblage of Jalodus and Siamodus. Fish remains stay in open nomenclature because isolated teeth are poorly diagnostic and could neither be used to determine specimens at genus level nor to estimate changes in fish communities through time.

\section{Specimen size}

Pre-Hangenberg levels (CT69-7 and CT70-A). - For all three groups, a general decrease in specimen size is observed between CT69-7 and CT70-A (Fig. 4). At the CT69-7 level, most of the shark material has been sorted from the $0.2 \mathrm{~mm}$ sieve while conodonts are most commonly found in the $0.4 \mathrm{~mm}$ sieve. Fishes are well represented in all fractions. Concerning level CT70-A, nearly all shark and fish teeth as well as conodonts $\mathrm{P} 1$ have been collected in the $0.2 \mathrm{~mm}$ sieve. For both levels, few elements have been found in the largest fractions $(>0.7 \mathrm{~mm})$ (Tab. 1, Fig. 2E). As the size of teeth seems to decrease in each group with no change in taxonomic diversity and as specimens do not present morphological characteristic of juveniles, we suggest that the decrease of teeth size testifies a decrease in body size.

Post-Hangenberg (CT70-5). - At the CT70-5 level, all specimens have been found in fractions $<0.7 \mathrm{~mm}$. Conodonts are almost equally represented in the $0.4,0.2$ and $0.1 \mathrm{~mm}$ fractions. Shark and fish teeth are very scarce at this level. However, sharks seem to be more present in the $0.4 \mathrm{~mm}$ fraction, with some representatives in the 0.2 and $0.1 \mathrm{~mm}$ fractions. For fishes, most of the fish teeth have been found in the smallest fraction $(0.1 \mathrm{~mm})$.

\section{Carbon isotope analyses}

Twenty seven samples from the base of CT69 to the top of the CT70 level have been analyzed for carbon isotopes. The first carbonate beds of CT70 have been sampled twice with $\delta^{13} \mathrm{C}$ showing consistent values. Some low $\delta^{13} \mathrm{C}$ values measured in 2014 (in italics, Tab. 3) have not been considered for reconstructing the general curve as these values are interpreted as diagenetically altered. The values from the former expansa to praesulcata conodont zones (ultimus Zone) show general decrease in $\delta^{13} \mathrm{C}$ from values between 2 to $3 \%$ in the Bi. ultimus (upper expansa) Zone to values around $1 \%$ above the Hangenberg crisis.

\section{Discussion}

\section{What conodonts, sharks and fishes can tell us when considered together?}

The Hangenberg crisis is defined by a global faunal turnover in vertebrate communities, exhibiting more extinctions than diversification of several taxa sometimes coupled with a strong Lilliput effect (Sallan \& Galimberti 2015). Studies on diversity in response to biological events are generally focusing on the event interval and concentrating on one taxonomic group, which does not allow to identify possible ecosystem reorganization. Our results cover the last million year preceding the Hangenberg crisis with the fauna already experiencing perturbations that induced restructuration at different levels of abundance and size (Fig. 2).

\section{Hangenberg pre-crisis (CT69-7 to CT70-A)}

The Devonian was a period of diversification including the rise of numerous vertebrates as bony fishes, cartilaginous fishes (sharks), conodonts and tetrapods (Sallan $\&$ Coates 2010). At the end of the Devonian, the time interval after the Epinette/Etreoungt to Hangenberg event has mostly been considered as a relatively quiet period (Fig. 1). Studies by Girard et al. (2014) and Aretz (2020) indicated relative stability in extinction rates of marine organisms, and carbon isotope curves published by Buggisch \& Joachimski (2006) and Matyja et al. (2021) indicate no major pertubations in the global carbon cycle.

In the Col des Tribes section, the gradual and small decrease in $\delta^{13} \mathrm{C}$ seems not to be related to any environmental perturbations contrary to the former Etroeungt/ Epinette event (Kaiser et al. 2008), which is supported by the carbonate facies of the three studied levels that seem not to vary representing of a stable outer ramp environment (Feist et al. 2020).

However, our results indicate some unexpected changes in the structure of vertebrate communities between two successive latest Famennian vertebrate assemblages, 1 my before the Hangenberg event. These differences are marked both by changes in assemblage composition (diversity and abundance) and size of the teeth remains (Figs 3, 4). Furthermore, considering that depositional environments were below or close to storm wave base throughout the studied time interval (Girard et al. 2014), fluctuations in sea level and depositional environment could contribute to the observed changes in the vertebrate community (Fig. 2). However, neither changes in sea level (Girard et al. 2014) nor major sedimentological changes (Feist et al. 2020) were recorded in the Col des Tribes section. The changes in the assemblage composition and the size of the remains that characterize the uppermost 


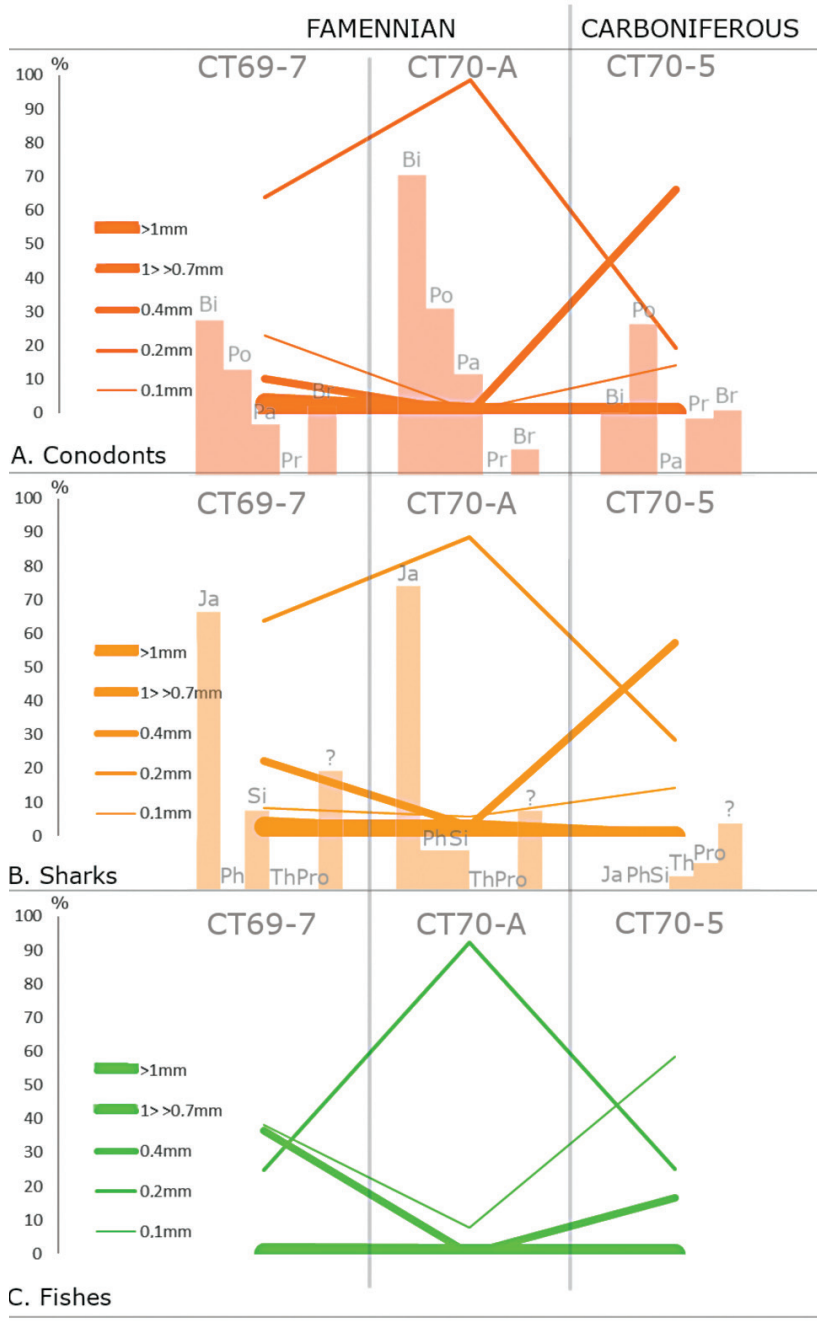

Figure 4. Abundance of fossils remains in our three temporal levels regarding to their size. $\cdot \mathrm{A}$ - conodonts. Abbreviations: $\mathrm{Bi}$ - Bispathodus; Po - Polygnathus; $\mathrm{Pa}$ - Palmatolepis; $\mathrm{Br}$ - Branmehla/Mehlina; $\mathrm{Pr}-$ Protognathodus. $・ \mathrm{~B}$ - sharks. Abbreviations: Ja - Jalodus; $\mathrm{Si}-$ Siamodus; ? - sharks indet; Ph - Phoebodus; Th - Thrinacodus; Pro Protacrodont indet. $\cdot \mathrm{C}$ - fishes. In transparency in A and B, abundancies of fossil genera in the three levels (Tabs 1,2).

part of the pre-Hangenberg Famennian cannot be related to a faunal turnover, because no major species replacement was observed, neither for conodonts (Girard et al. 2014) nor for sharks (Gauchey et al. 2014; this study). Conodonts and shark assemblages from the preHangenberg levels (CT69-7 and CT70-A) are composed of the same genera which seem not to present variations in terms of relative proportions. The decrease in the abundance of fish remains between CT69-7 and CT70-A is compensated by an increase in conodont abundance (Fig. 4). These observations are supported by the analysis of raw data extracted from the literature for conodonts (Girard et al. 2014) and fishes and sharks (Gauchey et al. 2014) (Fig. 5). In addition to results from this study, fishes and sharks from around the Hangenberg levels (Gauchey et al. 2014) reveal comparable abundances. Moreover, Gauchey et al. (2014) as well as this study document an obvious decrease in fish abundance remains through the Bi. ultimus Zone (between the former expansa and praesulcata zones) (Fig. 5). This suggests that marine ecosystems were affected differently during this socalled "relatively quiet period" compared to the terminal Hangenberg extinction, inducing changes in repartition of vertebrate groups in the ecosystem rather than a faunal turnover, since these time levels are not marked by any extinction of conodonts (Spalletta et al. 2017) and sharks (Ginter 2000). Just before the Hangenberg crisis (between CT69-7 and CT70-A), changes in size of teeth between CT69-7 and CT70-A (Fig. 2), considered here as change in body size of the teeth bearers (Luer et al. 1990, Purnell 1994, Gabbott et al. 1995, Chavez et al. 2012), coupled with

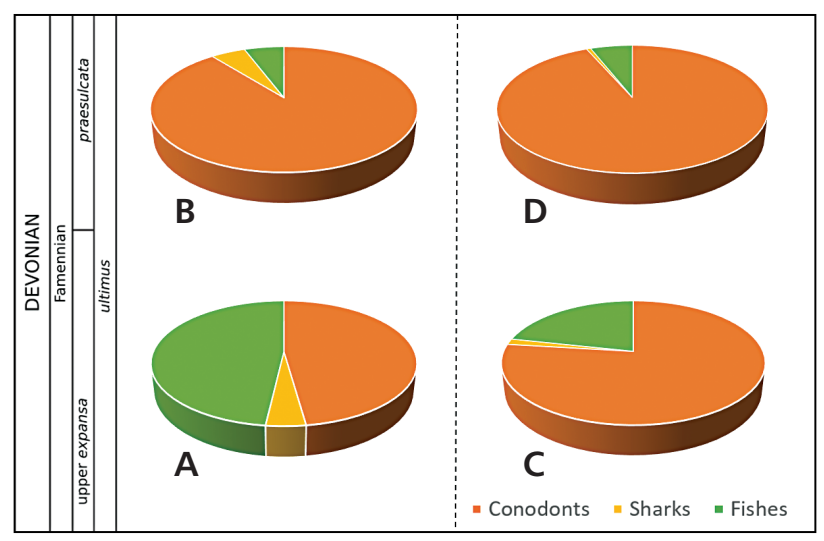

Figure 5. Comparison of the abundance of marine vertebrate remains in the Col des Tribes section. A, B - this paper; C, D - data from the literature from Gauchey et al. (2014) and Girard et al. (2014).

changes in the repartition of the vertebrate assemblages are probably underlining the relationship between these marine groups. The evolution of the abundance and size of these groups could be explained by natural competition among them, all living in the same ecological niche (Bengtsson 1989). A strong pressure on feeding resources could have favored opportunistic feeders. In the CT69-7 level, where conodonts and fishes are equally represented, we observe a wide size range for fish teeth that could allow predate a wide range of prey. In the CT70-Alevel, only small sized fish and conodont remains are observed, the latter dominating in terms of abundance. Coupled with a loss in abundance of fishes, this could be interpreted as a change in the ecological/trophic niche occupied by fishes. At the same time, conodonts also show a decrease in size but this decrease is correlated with an increase in abundance. Both phenomena could be explained by competition between these two groups. 
Numerous studies present fishes as conodont predators (e.g. Choo et al. 2009, Zaton et al. 2017). Considering changes in resource availability, we suggest a nonlinear trophic chain where conodonts could be as well prey and competitor for fish communities. The notable loss of fishes could be explained by the fact that they did not succeed to predate conodonts in the studied levels. This could suggest that conodont animals were highly competitive marine organisms and should be considered as an opportunistic group, i.e. a group specialized in invading newly vacated habitats where there was little competition from other groups or where other groups were unable to establish (Rodland \& Bottjer 2001).

This could explain the success of conodonts in invading all epicontinental Devonian seas (Klapper \& Johnson 1980). On the other hand, fishes could have been more impacted by changes in the available prey, indicating that they were more specialized feeders. Independently, fluctuations in vertebrate size have been tentatively correlated to changes in temperature (Ray 1960, PincheiraDonoso et al. 2008), the decrease in the size of vertebrates with increasing temperature described by Bergmann's rule. However, palaeoclimatological studies of the Late Devonian suggested global cooling just before the Hangenberg crisis (Buggisch et al. 2008, Issacson et al. 2008, Kaiser et al. 2008, Joachimski et al. 2009, Zhang et al. 2021). As studied levels cover a short period (hundreds of thousands of years), we cannot exclude a local increase in temperature, as suggested by the data published by Girard et al. (2020) for the Col des Tribes section, but without detailed temperature analyses in this area, further interpretations of the relationship between size and temperature variations are not possible.

The Lilliput effect has also been described, introducing the fact of a strong decrease in size after a crisis period (Harries \& Knorr 2009, Song et al. 2011). We observe that when conodonts became the dominant group of the marine vertebrates, the teeth of all groups (conodonts, bony fishes and sharks) were of similar small size. We suppose that the Lilliput effect could have affected shark, fish and conodont communities before the Hangenberg crisis and acted as an answer to resource competition linked to perturbations at the base of the trophic chain (Twitchett 2006, Brom et al. 2016, Rita et al. 2019) that occurred between CT69-7 and CT70-A during the last million year before the Hangenberg crisis (Fig. 4). Studies have described a Lilliput effect with numerous fishes and foraminifers of small size occurring after the Hangenberg event (Aretz et al. 2014, Sallan \& Galimberti 2015). However, regarding the relative abundances and sizes of conodonts, sharks and fishes, it could be considered that the Lilliput effect happened prior to the Hangenberg and that the impact of this Lilliput effect differs regarding each group (Schaal et al. 2015). As conodonts seems to benefit from the crisis in terms of abundance, it might be suggested that their shift in size involved that feeding resources became scarcer, but without a major change in their preys across time. This scenario could have favored small individuals and allow them to subsist as they present lower metabolic requirement (Calder 1984, Harries et al. 1996, Chen et al. 2019). The strong decrease in fish communities could be explained by a different scenario, considering that their preys were more drastically impacted by the global perturbations preceding the Hangenberg event and drove fishes to feed on other organisms, less represented and that did not allow to maintain large fishes communities. Sharks were very scarce in these levels but specimens that have been uncovered seem not to present changes in size supposing that they were less affected during the transition from CT69-7 and CT70-A.

\section{Post-Hangenberg crisis (CT70-A to CT70-5)}

In contrast to the relative stability of taxonomic diversity between the pre-Hangenberg levels CT69-7 and CT70-A, the Hangenberg crisis, which is recognized as a major extinction event, has induced a significant turnover in marine groups as for example conodonts and sharks (e.g. Walliser 1996, Ginter 2000, Kaiser et al. 2008). This is characterized in the Col des Tribes section by a strong decrease in the amount of specimens (nearly three times lower than before the crisis). However, relative abundances of sharks, conodonts and fishes did not change across the crisis, supposing that the ecosystem reached a trophic balance with a probable lack of ecological niche turnover inducing that the replacement of pre-Hangenberg taxa has not lead to a trophic restructuration.

Regarding the pre- and post-Hangenberg impacts on biodiversity, we argue that the crises that affected the uppermost Famennian faunas and led to the the Hangenberg extinction have acted in different ways. First, a preHangenberg restructuration of faunas with no faunal turnover and on the other hand the post-Hangenberg turnover that did not affect the repartition of the main marine vertebrate groups. The perturbations registered around the Hangenberg crisis in the Montagne Noire should be investigated in other localities to understand whether the observed faunal restructuration depends on local or more global perturbations.

\section{Conclusions}

Crises selectivity can be expressed in different ways. Here we demonstrate that the study of faunal turnover through time is not sufficient to understand the whole perturbations around crises. It appears that changes in community sizes and abundances prefigure the Hangenberg event even if 
faunal composition remains unchanged. In the Col des Tribes section, the three levels from the last million years before the Hangenberg event document changes that were not previously highlighted and give more clues about the timing and shaping of marine vertebrate communities at the edge of the Hangenberg crisis. The changes are not linked to major environmental perturbations as evidenced by facies and the carbon isotope record but indicate that community restructuration occurred even in relatively stable environments.

\section{Acknowledgements}

The authors acknowledge Jean-Jacques Cornée (Géosciences, Montpellier, France) for helping us with the stratigraphic log and facies descriptions of the Col des Tribes outcrop. We also thank Mathilde Bouchet-Combe (IGFL, Lyon, France) for help and access to the platform of microtomography at the ENS Lyon and Anne-Lise Charruault (ISEM, Montpellier, France) for giving us technical support to prepare carbonate powders. We also acknowledge Michal Ginter (University of Warsaw, Poland) for helping us with the identification of chondrichtyans. We are grateful to Felix Nesme (Lyon, France) for helping us on the field. We would like to thank Sandra Kaiser and Markus Aretz for reviewing this contribution and providing significant improvements. This is contribution ISEM 2021-257.

\section{References}

Aretz, M. 2020. Late Devonian extinction. Encyclopedia of Geology, $2^{\text {nd }}$ edition.

DOI 10.1016/B978-0-12-409548-9.12453-4

Aretz, M., Nardin, E. \& VAChard, D. 2014. Diversity patterns and palaeobiogeographical relationships of latest DevonianLower Carboniferous foraminifers from South China: What is global, what is local? Journal of Palaeogeography 3(1), $35-59$.

Aretz, M., Corradini, C., Cornée, J.-J., Feist, R. \& Girard, C. 2016. A new look on the Devonian-Carboniferous Boundary. 29 pp. Fieldguide to the DCB section in the SE Montagne Noire. International Workshop of the joined SDS-SCCS Task Group, Montpellier Sept. 2016.

Averbuch, O., Tribovillard, N., Devleeschouwer, X., Riquier, L., Mistiaen, B. \& Van Vliet-Lanoe, B. 2005. Mountain building-enhanced continental weathering and organic carbon burial as major causes for climatic cooling at the FrasnianFamennian boundary (c. $376 \mathrm{Ma}$ )? Terra Nova 17, 25-34. DOI 10.1111/j.1365-3121.2004.00580.x

Bambach, R., Knoll, A. \& Wang, S. 2004. Origination, extinction, and mass depletions of marine diversity. Paleobiology 30(4), 522-542.

DOI 10.1666/0094-8373(2004)030<0522:OEAMDO >2.0.CO;2

Becker, R.T., Gradstein, F.M. \& Hammer, O. 2012. The Devonian Period, 559-603. In Gradstein, F.M., OGG, J.G.,
Schmitz, M. \& OgG, G. (eds) The Geologic Time Scale 2012. Elsevier. DOI 10.1016/B978-0-444-59425-9.00022-6

Becker, R.T., Kaiser, S.I. \& Aretz, M. 2016. Review of chrono-, litho- and biostratigraphy across the global Hangenberg Crisis and Devonian-Carboniferous Boundary. Geological Society London, Special Publication 423, 355-386. DOI 10.1144/SP423.10

Bengtsson, J. 1989. Interspecific competition increases local extinction rate in a metapopulation system. Nature 340 , 713-715. DOI 10.1038/340713a0

Bischoff, G. 1957. Die Conodonten-Stratigraphie des rhenoherzynischen Unter-Karbons. Abhandlungen des Hessischen Landesamtes für Bodenforschung 19, 1-64.

Branson, E.B. 1934. Conodonts from the Hannibal Formation of Missouri. Missouri University Studies 8, 301-343.

Branson, E.B. \& Meht, M.G. 1934a. Conodonts from the Grassy Creek shale of Missouri. Missouri University Studies 8, 171-259.

Branson, E.B. \& Mehl, M.G. 1934b. Conodonts from the Bushberg sandstone and equivalent formations of Missouri. Missouri University Studies 4, 265-300.

Brom, K.R., Niedźwiedzki, R., Brachaniec, T., Ferré, B. \& Salamon, M.A. 2016. Environmental control on shell size of Middle Triassic bivalve Plagiostoma. Carnets de géologie 16(10), 297-305. DOI 10.4267/2042/60118

Buggisch, W. \& Joachimski, M.M. 2006. Carbon isotope stratigraphy of the Devonian of Central and Southern Europe. Palaeogeography, Palaeoclimatology, Palaeoecology 240, 68-88. DOI 10.1016/j.palaeo.2006.03.046

Buggisch, W., Joachimski, M.M., Sevastopulo, G. \& Morrow, J.R. 2008. Mississippian $\delta^{13} \mathrm{C}_{\text {carb }}$ and conodont apatite $\delta^{18} \mathrm{O}$ records - Their relation to the Late Palaeozoic Glaciation. Palaeogeography, Palaeoclimatology, Palaeoecology 268, 273-292. DOI 10.1016/j.palaeo.2008.03.043

Calder III, W.A. 1984. Size, Function, and Life History. 431 pp. Dover Publications, Mineola.

Chavez, S., Zufan, S., Kim, S.H. \& Shimada, K. 2012. Tooth sizes as a proxy for estimating body lengths in the porbeagle shark, Lamna nasus. Journal of Fossil Research (45), 1-15.

Chen, J., Song, H., He, W., Tong, J., Wang, F. \& Wu, S. 2019. Size variation of brachiopods from the Late Permian through the Middle Triassic in South China: Evidence for the Lilliput Effect following the Permian-Triassic extinction. Palaeogeography, Palaeoclimatology, Palaeoecology 519, 248-257. DOI 10.1016/j.palaeo.2018.07.013

Choo, B., Long, J.A. \& Trinasstic, K. 2009. A new genus and species of basal actinopterygian fish from the Upper Devonian Gogo Formation of Western Australia. Acta Zoologica 90, 194-210. DOI 10.1111/j.1463-6395.2008.00370.x

Decombeix, A., Meyer-Berthaud, B. \& Galtier, J. 2011. Transitional changes in arborescent lignophytes at the Devonian-Carboniferous boundary. Journal of the Geological Society 168, 547-557. DOI 10.1144/0016-76492010-074

Derycke, C., Blieck, A. \& Turner, S. 1995. Vertebrate microfauna from the Devonian/Carboniferous boundary stratotype at La Serre, Montagne Noire (Herault, France). Bulletin $d u$ Museum national d'Histoire Naturelle 17, 461-485. 
Druce, E.C. 1969. Devonian and Carboniferous conodonts from Bonaparte Gulf Basin, Northen Australia. Bureau of Mineral Resources. Geology and Geophysics Bulletin 69, 1-243.

Feist, R. \& Flajs, G. 1987. La limite Dévonien-Carbonifère dans la Montagne Noire (France). Biostratigraphie et environnement. Comptes rendus de l'Académie des Sciences de Paris 305, 1537-1544.

Feist, R., Flajs, G. \& Girard, C. 2000. The stratotype section of the Devonian-Carboniferous Boundary. Courier Forschungsinstitut Senckenberg 225, 77-82.

Feist, R., Cornee, J.J., Corradini, C., Hartenfels, S., Artez, M. \& GIRARD, C. 2020. The Devonian-Carboniferous boundary in the stratotype area (SE Montagne Noire, France). Palaeobiodiversity and Palaeoenvironments 101(2), 295-311. DOI 10.1007/s12549-019-00402-6

Gabbott, S.E., Aldridge, R.J. \& Theron, J.N. 1995. A giant conodont with preserved muscle tissue from the Upper Ordovician of South Africa. Nature 374, 800-803. DOI $10.1038 / 374800 \mathrm{a} 0$

Gauchey, S., Girard, C., Adnet, S., \& Renaud, S. 2014. Unsuspected functional disparity in Devonian fishes revealed by tooth morphometrics? Naturwissenschaften 101, 735-743. DOI 10.1007/s00114-014-1211-1

Ginter, M. 2000. Late Famennian pelagic shark assemblages. Acta Geologica Polonica 50, 369-386.

GiRARD, C. 1994. Conodont biofacies and event stratigraphy across the $\mathrm{D} / \mathrm{C}$ boundary in the stratotype area (Montagne Noire, France). Courier Forschung-Institut Senckenberg 168, 299-309.

Girard, C. \& Albarède, F. 1996. Trace elements in conodont phosphates from the Frasnian/Famennian boundary. Palaeogeography, Palaeoclimatology, Palaeoecology 126, 195-209. DOI 10.1016/S0031-0182(96)00114-9

Girard, C., Cornee, J.-J., Corradini, C., Fravalo, A. \& Feist, R. 2014. Palaeoenvironmental changes at Col des Tribes (Montagne Noire, France), a reference section for the Famennian of north Gondwana-related areas. Geological Magazine 151(5), 864-884.

DOI $10.1017 / \mathrm{S} 0016756813000927$

Girard, C., Cornée, J.-J., Joachimski, M.M., Charruault, A.-L., Dufour, A., Renaud, S. 2020. Paleogeographic differences in temperature, water depth and conodont biofacies during the Late Devonian. Palaeogeography, Palaeoclimatology, Palaeoecology 549, 108852.

DOI 10.1016/j.palaeo.2018.06.046

Goddéris, Y. \& JoAchimski, M.M. 2004. Global change in the Late Devonian: modelling the Frasnian-Famennian short-term carbon isotope excursions. Palaeogeography, Palaeoclimatology, Palaeoecology 202, 309-329. DOI 10.1016/S0031-0182(03)00641-2

Hallam, A. \& Wignall, P.B. 1997. Mass extinctions and their aftermath. 320 pp. Oxford University Press, Oxford.

Harries, P. \& Knorr, P. 2009. What does the 'Lilliput Effect' mean? Palaeogeography, Palaeoclimatology, Palaeoecology 284, 4-10. DOI 10.1016/j.palaeo.2009.08.021

Harries, P. J., Kauffman, E.G. \& Hansen, T.A. 1996. Models for biotic survival following mass extinction, 41-60. In HART,
M.B. (ed.) Biotic Recovery from Mass Extinction Events. Geological Society London, Special Publication 102.

DOI 10.1144/GSL.SP.1996.001.01.03

Isaacson, P., Díaz-Martínez, E., Grader, G., Kalvoda, J., Babek, O. \& Devuyst, F. 2008. Late Devonian-earliest Mississippian glaciation in Gondwanaland and its biogeographic consequences. Palaeogeography, Palaeoclimatology, Palaeoecology 268, 126-142.

DOI 10.1016/j.palaeo.2008.03.047

Joachimski, M.M., Pancost, R.D., Freeman, K., OstertagHenning, C. \& Buggisch, W. 2002. Carbon isotope geochemistry of the Frasnian-Famennian transition. Palaeogeography, Palaeoclimatology, Palaeoecology 181, 91-109. DOI 10.1016/S0031-0182(01)00474-6

Joachimski, M.M., Breisig, S., Buggisch, W., Talent, J.A., Mawson, R., Gereke, M., Morrow, J.R., Day, J. \& Weddige, K. 2009. Devonian climate and reef evolution: Insights from oxygen isotopes in apatite. Earth and Planetary Science Letters 284(3-4), 599-609. DOI 10.1016/j.epsl.2009.05.028

Kaiser, S., Steuber, T. \& Becker, R. 2008. Environmental change during the Late Famennian and Early Tournaisian (Late Devonian-Early Carboniferous): implications from stable isotopes and conodont biofacies in southern Europe. Geological Journal 43, 241-260. DOI 10.1002/gj.1111

Kaiser, S., Becker, R.T., Spalletta, C. \& Steuber, T., 2009. Highresolution conodont stratigraphy, biofacies and extinctions around the Hangenberg Event in pelagic successions from Austria, Italy and France. Palaeontographica Americana 63, 97-139.

Kaiser, S., Aretz, M. \& Becker, R. 2015. The global Hangenberg Crisis (Devonian-Carboniferous transition): review of a first-order mass extinction. In BeCKer, R.T., Konigshof, P. \& Brett, C.E. (eds) Devonian Climate, Sea Level and Evolutionary Events. Geological Society London, Special Publication 423. DOI 10.1144/SP423.9

Kaiser, S., Kumpan, T. \& Rasser, M.W. 2020. High-resolution conodont biostratigraphy in two key sections from the Carnic Alps (Grüne Schneid) and Graz Paleozoic (Trolp) implications for the biozonation concept at the DevonianCarboniferous boundary. Newsletters on Stratigraphy 53(3), 249-274. DOI 10.1127/nos/2019/0520

Klapper, G. \& Johnson, J.G. 1980. Endemism and dispersal of Devonian conodonts. Journal of Paleontology 54, 400-455.

Kravchinsky, V. 2012. Paleozoic large igneous provinces of Northern Eurasia: Correlation with mass extinction events. Global and Planetary Change 86-87, 31-36. DOI 10.1016/j.gloplacha.2012.01.007

Kulagina, E.I., Zaytseva, E.L., Vevel, Y.A., Stepanova, T.I., Gibshman, N.B., Nikolaeva, S.V., Kononova, L.I. \& Plotitsyn, A.N. 2021. The foraminiferal zonal scale of the Devonian-Carboniferous boundary beds in Russia and Western Kazakhstan and its correlation with ammonoid and conodont scales. Palaeobiodiversity and Palaeoenvironments 101, 561-588. DOI 10.1007/s12549-020-00439-y

Lebrun, R. 2018. MorphoDig, an open-source 3D freeware dedicated to biology. IPC5, Paris, France; 07/2018. https://hal. archives-ouvertes.fr/hal-01876987/file/S16_10_Lebrun.pdf 
Lelievre, H. \& Derycke, C. 1998. Les micro restes de vertébrés de la limite Dévonien-Carbonifère du sud de la chine (province du Hunan) et leur signification biostratigraphique. Revue de Micropaléontologie 41, 297-320. DOI 10.1016/S0035-1598(98)90205-7

Long, J. 1990. Late Devonian Chondrichthyans and Other Microvertebrate Remains from Northern Thailand. Journal of Vertebrate Paleontology 10, 59-71. DOI 10.1080/02724634.1990.10011790

Luer, C.A., Blum, P. \& C. Gilbert, P.W. 1990. Rate of Tooth Replacement in the Nurse Shark, Ginglymostoma cirratum. Copeia Vol. 1990(1), 182-191. DOI 10.2307/1445834

McGhee, G. 1996. The Late Devonian Mass Extinction: The Frasnian/Famennian Crisis. 318 pp. Columbia University Press, USA.

McGhee, G., Clapham, M., Sheehan, P., Bottjer, D., Drose, L. 2013. A new ecological-severity ranking of major Phanerozoic biodiversity crises. Palaeogeography, Palaeoclimatology, Palaeoecology 370, 260-270.

DOI 10.1016/j.palaeo.2012.12.019

Matyja, H., Woroncowa-Marcinowska, T., Filipiak, P., Branski, P. \& Sobien, K. 2021. The Devonian/Carboniferous boundary interval in Poland: multidisciplinary studies in pelagic (Holy Cross Mountains and Sudetes) and ramp (Western Pomerania) successions. Palaeogeography, Palaeoclimatology, Palaeoecology 101, 421-472.

DOI 10.1007/s12549-020-00442-3

Paproth, E., Feist, R. \& Flajs, G. 1991. Decision on the Devonian-Carboniferous boundary stratotype. Episodes 14(4), 331-336. DOI 10.18814/epiiugs/1991/v14i4/004

Paschall, O., Carmichael, S., Konigshof, P., Waters, J., Ta, P., Komatsu, T. \& Dombrowski, A. 2019 The DevonianCarboniferous boundary in Vietnam: Sustained ocean anoxia with a volcanic trigger for the Hangenberg Crisis? Global and Planetary Change 175, 64-81.

DOI 10.1016/j.gloplacha.2019.01.021

Pincheira-Donoso, D., Hodgson, D. \& Tregenza, T. 2008. The evolution of body size under environmental gradients in ectotherms: why should Bergmann's rule apply to lizards? BMC Ecology and Evolution 8(1), 1-13. DOI 10.1186/1471-2148-8-68

Purnell, M.A. 1994. Skeletal ontogeny and feeding mechanisms in conodonts. Lethaia 27, 129-138. DOI 10.1111/j.1502-3931.1994.tb01567.x

Raup, D. \& Sepkoski, J. 1982. Mass extinctions in the marine fossil record. Science 215, 1501-1503.

DOI 10.1126/science.215.4539.1501

RAY, C. 1960. The application of Bergmann's and Allen's rules to the Poikilotherms. Journal of Morphology 106, 85-108. DOI 10.1002/jmor.1051060104

Rita, P., Nätscher, P., Duarte, L.V., Weis, R. \& De Baets, K. 2019. Mechanisms and drivers of belemnite body-size dynamics across the Pliensbachian-Toarcian crisis. Royal Society open science 6, 190494. DOI 10.1098/rsos.190494

Roberts, G. \& Mannion, P. 2019. Timing and periodicity of Phanerozoic marine biodiversity and environmental change. Scientific reports 9, 1-11. DOI 10.1038/s41598-019-42538-7
Rodland, D. \& Bottjer, D. 2001. Biotic Recovery from the End-Permian Mass Extinction: Behavior of the Inarticulate Brachiopod Lingula as a Disaster Taxon. Palaios 16 , 95-101. DOI 10.1669/0883-1351(2001)016<0095:BRFTEP $>2.0 . C O ; 2$

Sallan, L. \& Coates, M. 2010. End-Devonian extinction and a bottleneck in the early evolution of modern jawed vertebrates. Proceedings of the National Academy of Sciences 107(22), 101331-10135. DOI 10.1073/pnas.0914000107

Sallan, L. \& Galimberti, A. 2015. Body-size reduction in vertebrates following the end-Devonian mass extinction. Science 350, 812-815. DOI 10.1126/science.aac7373

Schaal, E.K., Clapham, M.E., Rego, B.L., Wang, S.C. \& Payne, J.L. 2015. Comparative size evolution of marine clades from the Late Permian through Middle Triassic. Paleobiology 42(1), 127-142. DOI 10.1017/pab.2015.36

Sepkoski, J. 1996. Patterns of Phanerozoic Extinction: a Perspective from Global Data Bases. In Walliser O.H. (ed.) Global Events and Event Stratigraphy in the Phanerozoic. Springer, Berlin, Heidelberg. DOI 10.1007/978-3-642-79634-0_4

Song, H., Tong, J. \& CHEN, Z.Q. 2011. Evolutionary dynamics of the Permian-Triassic foraminifer size: Evidence for Lilliput effect in the end-Permian mass extinction and its aftermath. Palaeogeography, Palaeoclimatology, Palaeoecology 308, 98-110. DOI 10.1016/j.palaeo.2010.10.036

Spalletta, C., Perri, M., Over, D., Corradini, C. 2017. Famennian (upper Devonian) conodont zonation: revised global standard. Bulletin of Geosciences 92(1), 31-57. DOI 10.3140/bull.geosci.1623

Stigall, A. 2012. Speciation collapse and invasive species dynamics during the Late Devonian "Mass Extinction". Geological Society of America Today 22(1), 4-9. DOI 10.1130/G128A.1

Turner, S. 1982. Middle Palaeozoic elasmobranch remains from Australia. Journal of Vertebrate Paleontology 2(2), 117-131. DOI 10.1080/02724634.1982.10011923

Twitchett, R.J. 2006. The palaeoclimatology, palaeoecology and palaeoenvironmental analysis of mass extinction events. Palaeogeography, Palaeoclimatology, Palaeoecology 232, 190-213. DOI 10.1016/j.palaeo.2005.05.019

Walliser, O. 1984. Pleading for a natural D/C boundary. Courier Forschung-Institut Senckenberg 67, 241-246.

Walliser, O. 1996. Global events in the Devonian and Carboniferous. In Walliser, O. (ed.) Global events and event stratigraphy in the Phanerozoic. Springer, Berlin, Heidelberg. DOI 10.1007/978-3-642-79634-0

Zaton, M., Broda, K., Qvarnström, M., Niedźwiedzki, G. \& Ahlberg, P.E. 2017. The first direct evidence of a Late Devonian coelacanth fish feeding on conodont animals. Science of Nature 104(3), 1-5. DOI $10.1007 / \mathrm{s} 00114-017-1455-7$

Zhang, X., JoAChIMSKi, M.M. \& Gong, Y. 2021. Late Devonian greenhouse-icehouse transition: New evidence from conodont d180 thermometry in the eastern Paleotethys (Lali section, South China). Chemical Geology 581, 120383.

DOI 10.1016/j.chemgeo.2021.120383 
Ziegler, W. \& LANe, H.R. 1987. Cycles in conodont evolution from Devonian to mid-Carboniferous, 147-164. In ALDRIDGE, R.J. (ed.) Palaeobiology of Conodonts. British Micropalaeontological Society Series.
Ziegler, W. \& SAndberg, A. 1990. Reflexions on Frasnian and Famennian stage boundary decisions as a guide to future deliberations. Newsletters on stratigraphy 33(3), 157-180. DOI 10.1127/nos/33/1995/157 